\title{
Upcoming meetings and courses
}

(C) The Author(s) 2014. This article is published with open access at Springerlink.com

EPOS 33rd annual meeting, Bruges 2014

2nd-5th April, 2014

Bruges, Belgium

For further information: http://www.epos2014.be/

Open Access This article is distributed under the terms of the Creative Commons Attribution License which permits any use, distribution, and reproduction in any medium, provided the original author(s) and the source are credited. 